Analysis

\title{
Volunteer and satisfied? Rural households' participation in a payments for environmental services programme in Inner Mongolia ${ }^{\text {s }}$
}

\author{
Sylvie Démurger ${ }^{\mathrm{a}, \mathrm{b}, \mathrm{c}, *}$, Adeline Pelletier ${ }^{\mathrm{d}, \mathrm{e}}$ \\ a Université de Lyon, Lyon F-69007, France \\ b CNRS, GATE Lyon Saint-Etienne, 93 Chemin des Mouilles, Ecully F-69130, France \\ c IZA, Bonn, Germany \\ d The Centre for Economic Performance, London School of Economics and Political Science, Houghton Street, London WC2A 2AE, United Kingdom \\ e Instituto de Empresa, IE University, María de Molina, 31 Bis. 28006 Madrid, Spain
}

\section{A R T I C L E I N F O}

\section{Article history:}

Received 27 November 2013

Received in revised form 3 April 2015

Accepted 9 April 2015

Available online $\mathrm{xxxx}$

\section{JEL Classification:}

Q15

Q57

Q58

053

Keywords:

Payments for environmental services

Sloping Land Conversion Programme

Household participation

Life satisfaction

China

\begin{abstract}
A B S T R A C T
Using survey data from Inner Mongolia, this paper explores the role of stakeholder engagement in the implementation of the Sloping Land Conversion Programme, a payments for environmental services (PES) programme designed to restore forest in degraded land. Based on the idea that volunteerism and satisfaction with the programme's outcome are two important components of the programme's viability, we successively analyse the intensity of households' participation in the programme and their reported satisfaction with its economic achievement, which we relate to their stated volunteerism. We show that households' participation intensity in the SLCP is primarily driven by land and location characteristics, and that these findings hold true whether or not the households voluntarily enrolled in the programme. Moreover, as far as participants' satisfaction can be interpreted as an indicator of potential long-term support for the programme, our findings also support plausible sustainability for the programme.
\end{abstract}

(C) 2015 Elsevier B.V. All rights reserved.

\section{Introduction}

Payments for environmental services (PES) programmes have quickly become important instruments in environmental and development policies worldwide. ${ }^{1}$ The core mechanism of PES schemes is to

\footnotetext{
th This paper is part of a research programme funded by the French Ministry of Higher Education and Research on "Forest Resources Protection and Local Population Welfare: Case Studies Comparison from China" (ACI 2003-2-579). The household survey has been designed and implemented by Sylvie Démurger, Martin Fournier, Pascal Marty and Weiyong Yang in collaboration with the Beijing University of Forestry and the Inner Mongolia Agricultural University. Sylvie Démurger wishes to thank Junqing Li as well as students from the Beijing University of Forestry and from the Inner Mongolia Agricultural University for the precious collaboration in carrying out the household survey. We are also grateful to three anonymous referees for the helpful comments and suggestions.

* Corresponding author at: CNRS, GATE Lyon Saint-Etienne, 93 Chemin des Mouilles, Ecully F-69130, France.

E-mail addresses: demurger@gate.cnrs.fr (S. Démurger), a.g.pelletier@lse.ac.uk (A. Pelletier).

${ }^{1}$ Rodriguez et al. (2011) provide an interesting discussion of policy tools used in the developing world to tackle environmental conservation and poverty alleviation, including PES programmes. See also Wunder (2005), Bulte et al. (2008), Engel et al. (2008) and Muradian et al. (2010).
}

create or to change stakeholders' incentives and behaviour so as to promote land management practices that generate ecosystem services and favour ecological restoration and/or conservation (see Rodriguez et al., 2011). For developing countries, PES schemes often entail the additional goal of achieving a win-win situation in terms of both environmental protection and poverty alleviation (Muradian et al., 2010).

The long-term sustainability of PES schemes crucially depends on how effective the incentive-based mechanism is at aligning stakeholders' individual land-use decisions with the social benefits arising from conservation. In this paper, we explore the issue of land use changes promoted by the Sloping Land Conversion Programme (henceforth, SLCP) in China, a government-financed PES programme designed to restore forest in degraded land through a public payment scheme. The SLCP is the largest land retirement programme in the developing world. It involves changing land uses by reforesting sloping land currently used in agriculture on the one hand, and by afforesting barren land on the other hand. Local farmers are selected based on the characteristics of their cropland, and they receive compensation in the form of an annual in-kind subsidy of grain, a cash subsidy and free seedlings, to convert degraded and highly sloping land back to either "ecological forests" (timber-producing forests), "economic forests" (orchards or 
plantations of trees with medicinal value) or grassland. Launched in three pilot provinces in 1999 and progressively scaled-up across 25 provinces until 2002, the programme's goal was to convert 14.7 million hectares of fragile cropland to forests by the end of the decade. The programme also had an explicit component of alleviating poverty in rural areas, with compensation payments provided to more than 50 million rural households upon completion of the programme (Uchida et al. 2007).

The SLCP has generated considerable academic interest regarding its effectiveness in terms of both ecological (Shi and Chen, 2004) and economic outcomes (Yin et al., 2010). So far, most economic papers have studied the impact of the policy on rural households' production and food security (Feng et al., 2005; Z. Xu et al., 2006; J. Xu et al., 2006), on peasants' income (Liang et al., 2012; Liu et al., 2010; Z. Xu et al., 2006; J. Xu et al., 2006; Yao et al., 2010), on poverty (Uchida et al., 2007) or on labour transfer into off-farm sectors (Démurger and Wan, 2012; Groom et al., 2010; Uchida et al., 2009; Yao et al., 2010). In contrast, the question of the long-run sustainability of the programme has received much less attention, although it is of obvious critical importance. One exception is Grosjean and Kontoleon (2009), who propose a direct ex-ante assessment of the viability of the programme by using farmers' contingent behaviour and choice experiment data collected in Ningxia and Guizhou provinces in the early phase of the programme's implementation. They find that the major constraints on the programme's sustainability are weak and incomplete property rights on the one hand, and high labour mobility transaction costs on the other hand. We propose a complementary approach to this question by assessing both rural households' ex-ante willingness to participate in the SLCP and their ex-post support for the programme. Since farmers are the main stakeholders in the SLCP framework, the feasibility and longlasting prospects of the programme can be reasonably expected to depend strongly on their perceptions of the programme's outcomes (Sommerville et al., 2010). Important for this are the degree to which rural households voluntarily participate ${ }^{2}$ the degree to which they benefit from the programme, ${ }^{3}$ and their general trust in the programme, since farmer mistrust may prevent the attaining of environmental goals, ${ }^{4}$ all dimensions that can be questioned in the case of China and thus deserve particular attention.

We utilize rural households' survey data collected in 2006 in Inner Mongolia to explore the role of stakeholder engagement in the implementation of the Sloping Land Conversion Programme and its implications for the programme's long-term sustainability. We proceed as follows. First, we seek to assess farmers' volunteerism and thus understand their involvement in the programme. To do so, we focus on the implementation modalities of the programme and on the determinants of households' intensity of participation. In particular, we seek to evaluate to what extent the intensity of participation is determined by household demographic characteristics and/or by geographic and location characteristics. Second, we explore what factors are associated with participating household perceptions regarding whether or not the programme has had a beneficial effect on their livelihoods. As well as contributing to the existing literature by combining measures of the intensity of participation and a subjective well-being approach, we also make use of more recent data compared to earlier studies, which

\footnotetext{
2 Bennett (2008) points out that one of the main drawbacks of the SLCP is that it is a mix of a PES and a top-down approach with campaign-style political mobilization, and it lacks effective volunteerism from rural stakeholders.

${ }^{3}$ Early papers have put forward shortfalls in compensation payments, with SLCP payments being lower than the net income derived from cultivating the retired land (Uchida et al., 2005) and shortfalls in delivered subsidies (Xu and Cao, 2001; Xu et al., 2010; Zuo, 2001).

${ }^{4}$ In the case of China, uncertainties arise from the limited time-horizon of the payments coupled with ambiguous property rights and changing government policies. Analysing responses from a 2003 survey to a question on what households would most likely do upon the end of the subsidy period, Bennett (2008) concludes that at least a fifth of retired cropland would be returned to cultivation. Grosjean and Kontoleon (2009) highlight institutional constraints as key obstacles to the long-term viability of the programme.
}

enables us to better capture the changes that have occurred since the start of the programme and the perceived benefits for rural households.

The paper is organized as follows. Section 2 describes the study area and database. Section 3 presents the analytical framework for examining the determinants of households' participation intensity and their satisfaction with respect to the programme. Section 4 presents the empirical results and Section 5 concludes.

\section{Study Area}

\subsection{Data}

Our analysis is based on data collected through a household survey that was implemented in 10 villages in Inner Mongolia in March 2006. The villages are situated in Zhuozi county of Wulanchabu prefecturelevel city, in central Inner Mongolia. The county is located $120 \mathrm{~km}$ from the provincial capital, Hohhot, in a northern temperate zone with a semi-arid continental monsoonal climate. Due to the mismanagement of land and overgrazing, the area has developed a fragile and damaged environment. It has been designated one of 42 key soil erosion counties in the upper and middle reaches of the Yellow River and one of Inner Mongolia's six counties with the most serious soil erosion.

The 10 administrative villages were purposely selected to reflect several criteria including accessibility, local economic opportunities, and programme implementation. Within each village, 30 to 60 households were randomly selected and interviewed on a face-to-face basis by enumerators hired from Beijing Forestry University and from the Inner Mongolia Agricultural University. Altogether, 481 households from 10 villages in 5 townships were interviewed. The data set includes detailed information at the household level and at the plot level. Family information includes household demography, members' activities, income and assets, access to credit, and energy consumption. Land information includes plot characteristics and utilization as well as information on land conversion and compensation received for conversion. In addition to household interviews, village-level information was also gathered so as to complement individual data by providing a general overview of the implementation arrangements at the village level.

\subsection{The Local Implementation of the Sloping Land Conversion Programme}

As in other parts of Inner Mongolia, the Sloping Land Conversion Programme has been implemented in Zhuozi county on a gradual basis from 2000 onwards. It started in 10 townships and was then extended to the 14 townships in the county by 2002. The implementation procedure for the SLCP in Zhuozi county followed the national arrangements of a top-down approach that left only small room for farmers to get involved on a truly voluntary basis. In particular, the target area for conversion was decided at the county level while the choice of tree species to be planted fell under the responsibility of the local forest bureau.

In addition to retiring their own cultivated land, ${ }^{5}$ participating households were also requested to afforest barren and degraded wasteland. The arrangement was that for each retired $\mathrm{mu}^{6}$ of cropland, households had to afforest between 1 and 2.5 mu of barren land that belonged to the village but was meant to be contracted to the household after afforestation. ${ }^{7}$ Participating farmers received an annual compensation that follows the national settings: a cash payment of 300 yuan per

\footnotetext{
${ }^{5}$ Land in rural China is owned by village collectives but it is contracted to households for their own productive use under a fixed-term contract (Brandt et al., 2002).

6 The conversion for China's land measurement unit is $1 \mathrm{mu}=1 / 15$ ha.

7 The conversion share of barren land to cropland varied over time (and across villages): it started at 2.5:1 in 2000, decreased to 2:1 in 2001 and 2002 before reaching a minimum of 1:1 from 2003 onwards. As argued by Bennett (2008), the additional goal of afforesting barren land imposed by the central government shifted nationwide from an explicit requirement for participation to an optional goal after participants protested against the significant labour requirement of the stipulation. See also Zuo (2001).
} 
hectare of cultivated land converted and a grain payment of $1500 \mathrm{~kg}$ per hectare. From 2004, the in-kind compensation was replaced by an additional annual cash compensation of 2100 yuan per hectare.

Interviews with local cadres (either the village head or party secretary) helped identify the overall achievements of the SLCP as well as the difficulties that they faced in the local implementation of the programme. Reported difficulties at the village level mostly occurred at the very beginning of the implementation period. They are, in decreasing order of importance, strong a priori resistance by villagers against the programme, the inappropriate choice of land plots to be converted, a low survival rate for planted trees or grass (together with the low quality of seedlings) and some delays in the payment of compensation. Anecdotal evidence indicates that when the programme was launched, village cadres often had to work hard at persuading their co-villagers to enrol in the programme, and some enrolled themselves in large conversions in order to set an example. The main reason for the initial strong reluctance was that peasants feared that they would never get the announced compensation payment. Nevertheless, attitudes towards the programme changed rapidly after the first couple of years of implementation and most peasants were actually reported to be eager to participate, even when quotas had already been fulfilled.

Despite the initial reluctance of households, the participation rate increased rapidly to reach a high level and, by $2006,85.5 \%$ of the surveyed households had been involved in cultivated land conversion. This high enrolment rate does not translate into homogenous conversion patterns though. On average, participating households have converted about half of their cultivated land but there are large differences across households, ${ }^{8}$ and some households converted all their land whereas others converted only a very small share. The time pattern of the conversion process also varies. Whereas in the first years of implementation of the programme few households enrolled in two consecutive years, this was no longer the case in the later years (Table 1). For instance, only $11 \%$ of the 117 households who converted land in 2001 had already converted land the year before. This proportion continuously increased with time, to reach 55\% of the 78 households who converted land in 2004.

Table 2 contains baseline characteristics for converted and nonconverted cultivated plots to illustrate land targeting in the area. Land characteristics clearly differ: converted plots are on average significantly larger, further away from the household home, with a steeper slope, and they were much less productive than non-converted plots. The main crop of converted plots in 2002, at the peak of the conversion period, was also more likely to consist of cereals (such as sesame and oats), whereas a significantly larger number of non-converted plots had potatoes as their main crop. Given the small average size of cultivated plots, the higher incidence of cereal crops for converted plots is an indicator of relatively low-return cropping activities before conversion. All these statistics illustrate the fact that the conversion in Zhuozi county predominantly targeted land with a lower agricultural value (less productive and with a steeper slope), in line with the stated objectives of the programme. Similar findings on land targeting by the SLCP have also been reported in the available literature: Gauvin et al. (2010), Uchida et al. (2007) and Xu et al. (2010) all find a significantly negative correlation between a plot's opportunity cost (as measured by its distance from home or its slope) and its enrolment in the SLCP.

\section{Empirical Framework}

\subsection{The Determinants of the Decision-making Process}

A central issue with the SLCP is that the programme was supposed to be based on voluntary participation. However, various empirical

\footnotetext{
8 The standard deviation of the share of land area converted for participating households is 0.24 . At the bottom end, $10 \%$ of the participating households have converted $18 \%$ or less of their cultivated land. At the top end, $10 \%$ of the participating households have converted $84 \%$ or more of their cultivated land.
}

Table 1

Evolution of converted area between 2000 and 2005.

Author's survey, Zhuozi county, Inner Mongolia, 2006.

\begin{tabular}{lllll}
\hline & $\begin{array}{l}\text { Participating households } \\
\text { with newly converted area }\end{array}$ & $\begin{array}{l}\text { Newly converted area } \\
(\mathrm{mu} / \text { household })\end{array}$ & $\begin{array}{l}\text { Of which: } \\
\text { Cultivated land }\end{array}$ & $\begin{array}{l}\text { Barren } \\
\text { land }\end{array}$ \\
\hline 2000 & 101 & 17.70 & 9.03 & 15.67 \\
2001 & 117 & 16.66 & 10.70 & 28.95 \\
2002 & 139 & 11.76 & 6.72 & 11.65 \\
2003 & 136 & 10.52 & 6.31 & 9.58 \\
2004 & 78 & 8.22 & 6.05 & 5.1 \\
2005 & 42 & 5.67 & 4.78 & 3.47 \\
\hline
\end{tabular}

Note: the number of participating households refers to households who converted land during the corresponding year, whether or not they had already converted land in the preceding year(s).

analyses have pointed out a rather authoritarian implementation that did not leave much autonomy for rural households in their decisionmaking process (e.g. Bennett, 2008; Mullan and Kontoleon, 2012; Xu et al., 2010). The summary statistics for our sample are consistent with this observation, although they also qualify one key aspect concerning the existence of different degrees of (non-)volunteerism. Table 3 reports responses by programme participants to questions about the programme's implementation and achievements. When asked why they converted part or all of their cultivated land, only $31 \%$ of participating households reported fully voluntary participation with no interference from village cadres. That said, another $49 \%$ declared that they converted their cultivated land because it was compulsory but that they wished to participate, and, in the end, only $20 \%$ felt that they had no choice and had to enrol. These figures give some interesting insights into the degree to which programme participation was voluntary or not. In particular, they indicate that, despite the fact that for $69 \%$ of the surveyed participants participation was not an individual choice, it was overwhelmingly felt to be non-coercive and quite welcome.

We use a fractional logit model (Papke and Wooldridge, 1996) ${ }^{9}$ to examine the determinants of households' programme participation intensity. We focus on the intensity of participation rather than on the participation decision per se because the participation rate is quite high in the area, and because we want to unravel potential differences in behaviour between different types of households grouped by their stated degree of volunteerism. Hence, the dependent variable is the intensity of households' participation in the SLCP, measured by the share of households' total (cultivated) land that is converted.

To assess the nature of households' decision-making process, we propose two types of empirical tests. First, we compare the impact of household characteristics to the impact of land characteristics on the intensity of participation: if land conversion is strictly exogenous to households and determined by programme administrators only, we should expect land characteristics to be the only determinants of participation intensity. Second, given that there seem to be different degrees of volunteerism, we may also expect participation models to be influenced by these differences. To test this, we also estimate separate models for three sub-samples of programme participants: $i$ ) nonvolunteered households, ii) partly-volunteered households and iii) fully-volunteered households. The definitions of these sub-groups are based on each household's answer to the question on the reason why they converted part or all of their cultivated land (see Table 3).

We consider two categories of explanatory variables. The first category corresponds to programme attributes, which are exogenous to households' characteristics and are related to the administrative decision to convert. This category includes land characteristics that could be used by the programme administrators as criteria for deciding who should be participating. Following the literature on the determinants

\footnotetext{
9 Such an approach is useful when the dependent variable is a proportion that falls between zero and one, which is the case here. Estimations are done using the 'glm' Stata routine with a logit transformation of the response variable and a binomial distribution.
} 
Table 2

Summary statistics for converted and non-converted plots.

Author's survey, Zhuozi county, Inner Mongolia, 2006.

\begin{tabular}{lcccl}
\hline Land characteristics & Non-converted & Converted & Total & $\begin{array}{l}\text { Difference } \\
\text { in means }\end{array}$ \\
\hline Plot size (mu) & 2.497 & 5.464 & 3.584 & $* * *$ \\
Plot productivity (t/mu) & 0.198 & 0.0672 & 0.158 & $* * *$ \\
Plot distance to home $(\mathrm{min})$ & 15.65 & 34.14 & 22.50 & $* * *$ \\
Plot distance to home $(\mathrm{km})$ & 0.641 & 1.305 & 0.884 & $* * *$ \\
With gentle slope & 0.565 & 0.570 & 0.567 & NS \\
With steep slope & 0.0137 & 0.373 & 0.145 & $* * *$ \\
Main crop in 2002: wheat & 0.0897 & 0.0933 & 0.0910 & NS \\
Main crop in 2002: sesame & 0.135 & 0.197 & 0.157 & $* * *$ \\
Main crop in 2002: oats & 0.137 & 0.256 & 0.180 & $* * *$ \\
Main crop in 2002: potatoes & 0.171 & 0.0721 & 0.135 & $* * *$ \\
Observations & 2620 & 1511 & 4131 & \\
\hline
\end{tabular}

Notes: In the last column the significance level of mean differences between converted and non-converted plots is indicated (NS: non-significant. ***Significant at $1 \%$ ). Some averages are calculated over a smaller number of observations because of missing values. We only report the total number for reference.

of SLCP participation (Mullan and Kontoleon, 2012; Uchida et al., 2007; Xu et al., 2010), we use the total size of plots, the total number of plots, the share of land area with a steep slope and the share of land area with a gentle slope as "programme attributes" variables. Ideally, we should also include an indicator for the income level of the household before the conversion in order to check whether the programme effectively targeted the poor (Uchida et al., 2007). However, our data set does not contain such information, and as a consequence we cannot examine the degree to which the programme also included poorer households. The second category comprises variables that are related to household socio-demographic characteristics and the perceived benefits of participation. The socio-demographic characteristics include the household

Table 3

Participating households' perceptions of the Sloping Land Conversion Programme's implementation and achievements.

Author's survey, Zhuozi county, Inner Mongolia, 2006.

\begin{tabular}{|c|c|}
\hline & Answers \\
\hline \multicolumn{2}{|l|}{ Implementation } \\
\hline $\begin{array}{l}\text { Why did you convert your agricultural } \\
\text { land? }\end{array}$ & $\begin{array}{l}\text { Wished to convert } \\
\text { (fully-volunteered): } 31 \% \\
\text { Compulsory enrolment and wished } \\
\text { to convert (partly-volunteered): } 49 \% \\
\text { Compulsory enrolment } \\
\text { (non-volunteered): } 20 \%\end{array}$ \\
\hline $\begin{array}{l}\text { Have you received specific training in forest } \\
\text { plantation? }\end{array}$ & Yes: $54 \%$ \\
\hline
\end{tabular}

\section{Achievements}

What is the average survival rate of planted $78 \%$ (standard deviation: $14 \%$ ) trees or grass?

How did the agricultural yield of converted land compare to non-converted land?
O Higher: $21 \%$
Identical: $18 \%$
O Lower: $61 \%$
Yes: $84 \%$

s land conversion
land cultivation?

How much is received in total subsidies (cash and in-kind) compared to agricultural production?

Has conversion led to an increase in off-farm activities in your household?

Has conversion led to an increase in migration in your household?

Compared to its level before conversion, do you think that your living standards have improved, remained unchanged or deteriorated with the SLCP? size and composition as well as the household head's human capital (age and education). The households' level of information about the policy is captured through their political capital (in the form of membership of the village committee), the remoteness of the household (measured by the household home's distance to an asphalt road and to the village centre), and programme duration (the number of years since first participation).

\subsection{Households' Satisfaction with the Programme}

One innovation of the survey is that the participants were asked subjective questions on their appreciation of the programme. This allows us to assess the success and benefits of the SLCP as perceived by local farmers who took part in the programme. First, the evidence reported in Table 3 indicates general satisfaction with the programme's outcomes. In terms of general benefits, $70 \%$ of the households considered that conversion had had a positive effect on their living standards, while only $3 \%$ considered that their living standards deteriorated after participating in the programme and the remaining quarter felt that there was no change. A large majority (84\%) of the participating households considered that it was more profitable to convert land than to keep cultivating. Similarly, $72 \%$ considered that the compensation offered to participating households exceeded the benefit they would have received from cultivating their land. Subjective assessment data also suggest that land conversion was relatively well-targeted and profitable since households reported an average survival rate for planted trees of $78 \%,{ }^{10}$ and they declared that the agricultural yield of converted land was typically lower than that of non-converted land. ${ }^{11}$ Finally, the conversion allowed households to diversify their activities to a certain extent, since half of them increased their participation in migration and $58 \%$ increased their local off-farm activities.

To investigate the factors influencing participating households' satisfaction with the programme, we use the question on the impact of the programme on households' living standards (Table 3, last row) to create a binary variable that takes the value of 1 if the household declares an improvement in its living standards related to the SLCP and 0 otherwise. We call this variable "satisfaction" under the assumption that households who declare that their livelihoods have improved due to the programme are also more likely to be more satisfied. Furthermore, we seek to relate households' perceptions regarding whether or not the programme has had a beneficial effect on their livelihoods to their reported degree of volunteerism in programme participation by differentiating household types. As for participation intensity, we distinguish three household types: fully-volunteered households, partlyvolunteered households and non-volunteered households (the latter being the reference group here). The household type is likely to be endogenous because it is a choice variable potentially correlated with unobservables that also affect reported satisfaction. ${ }^{12}$ In order to account for this potential endogeneity, we use a recursive trivariate probit model, as illustrated below:

$$
\left\{\begin{array}{l}
y_{i 1}^{*}=\beta_{1} X_{i 1}+\gamma y_{i 2}+\delta y_{i 3}+\varepsilon_{i 1} \\
y_{i 2}^{*}=\beta_{2} X_{i 2}+\varepsilon_{i 2} \\
y_{i 3}^{*}=\beta_{3} X_{i 3}+\varepsilon_{i 3}
\end{array}\right.
$$

with $y_{i m}=1(m=1,2,3)$ if $y_{i m}^{*}>0$ and 0 otherwise.

\footnotetext{
${ }^{10}$ As noted by Bennett (2008), the State Forestry Administration stipulated a nationwide target of $75 \%$ for the survival rate. Reported survival rates in Zhuozi county are thus in line with official standards.

11 One should note that $21 \%$ of the agricultural yield of converted land was still reported as being higher than the yield of the non-converted land. This could signal some partial mis-targeting of plots for conversion. Using 2003 survey data from Shaanxi, Gansu and Sichuan, Xu et al. (2010) pointed out a significant mis-targeting of fertile flatland for retirement.

${ }^{12}$ For instance, more optimistic households might have been more likely to volunteer for SLCP conversion and might also be more likely to be satisfied, ceteris paribus. In this case, estimating a simple probit would give an upward-biased estimate.
}

Notes: The total number of participating households is 411 Some statistics are calculated over a smaller number of observations because of missing values (the lowest is 396 observations for the question "Has conversion led to an increase in migration in your household?"). 
This approach allows estimating simultaneously the factors that determine satisfaction with the $\operatorname{SLCP}\left(y_{1}\right)$, as well as the factors that determine fully-volunteered participation $\left(y_{2}\right)$ and partly-volunteered participation $\left(y_{3}\right){ }^{13}$ The parameters of interest for us are $\gamma$ and $\delta$, which measure conditional differences in the probabilities of reporting a positive perception regarding the impact of the SLCP between fullyvolunteered and non-volunteered households respectively, and between partly-volunteered and non-volunteered households. The exclusion restrictions we use in the fully-volunteered and partly-volunteered participation equations are the shares of fully-volunteered and partlyvolunteered households in the village. The rationale for using these instruments is that we may expect some peer effects in volunteerism so that larger volunteerism at the village level may influence individual households' own volunteerism, whereas it should not be correlated with the error term in the individual satisfaction equation.

We consider two groups of explanatory variables in the $X_{1}$ matrix for the satisfaction equation. The first one captures the participation experiences of households (besides their degree of volunteerism captured by $y_{2}$ and $y_{3}$ ), measured by the length of household participation in the programme (in years) and the share of land area converted. The second one captures the fact that the benefits of participation for households are heterogeneous and depend on household demographics (age and education of the household head, household size and composition, village committee membership), household land assets and income, and location. Regarding income, we follow the literature on subjective well-being and introduce indicators of households' absolute as well as relative income levels as explanatory variables (Ferrer-i-Carbonell, 2005). Relative income is defined as the gap between a household's total income and the average income of a reference group. ${ }^{14}$ Households in the same village are taken as the reference group because the level of interaction between households of different villages is relatively low.

\section{Results}

\subsection{Participation Intensity in the SLCP}

As a first step in analysing the determinants of households' participation, Table 4 compares non-participating and participating households and, among participating households, fully-volunteered, partlyvolunteered and non-volunteered households. First, the comparison between participating and non-participating households reveals clear differences in land and location characteristics. Both the number of plots and total land area are significantly much higher for participating households: the number of plots is on average 2.2 times higher and the total land size is on average 3.8 times larger. Their endowment of sloping land is also more than twice that of non-participating households (more than $70 \%$ of their land against $30 \%$ ). Finally, whereas participating households live in much less remote places, with an average distance to the village centre that is almost twice as small (1.1 km against $1.9 \mathrm{~km})$, they live further from their cultivated land compared to nonparticipating households $(0.882 \mathrm{~km}$ against $0.610 \mathrm{~km})$. Participating and non-participating households also differ in certain demographic characteristics. In particular, participating households are on average significantly larger and younger: the average participating household size is 3.3 persons (against 2.5 for non-participating households), with an average age for the head of household slightly above 55 and a share of elderly people that is twice as small. On the other hand, the two groups share a low level of human capital and similar characteristics in terms of local political life participation.

The comparison of fully-volunteered, partly-volunteered and nonvolunteered participating households provides additional insights

\footnotetext{
13 The model is estimated using the 'mvprobit' Stata routine (Cappellari and Jenkins, 2003). Township fixed effects are introduced.

${ }^{14}$ More precisely, we take the difference between the logarithm of the household's own income $\ln \left(y_{i}\right)$ and the logarithm of the average income of the reference group $\ln \left(y_{r}\right)$
}

into the nature of programme participation and volunteerism. Nonvolunteered households share similar demographic characteristics with other participating households (both fully-volunteered and partly-volunteered) but they differ in two key land and location characteristics: their land area and number of plots on the one hand, and their homes' distance to an asphalt road on the other hand. They have access to less land (32 mu of cropland compared to $39 \mathrm{mu}$ for fullyvolunteered households) but potentially less scattered land (with a significantly smaller number of plots per household) than other participating households, and they live in less remote places. Since less scattered plots and households living close to the village are likely to be easier to monitor, these two characteristics could represent potentially important criteria for village leaders' selection regarding who should participate. This is in line with Xu et al. (2010), who found evidence of minimization of transaction cost considerations in the SLCP implementation, although they also pointed out that targeting plots close to roads could also be reflecting "showcase" implementation by local leaders. In contrast, fully-volunteered households exhibit significantly less favourable characteristics regarding the main programme attributes: they have a smaller share of land with a steep slope, they have more plots and they live much further from the road.

Table 5 presents the marginal effects for an average household of the fractional logit estimations of participation intensity. Since one may expect that households from one village are more alike in terms of the survey than households in general because of similar local conditions or neighbourhood effects, the estimations allow for intra-village correlations through a cluster effect. We examine five different samples in turn. The first one includes all the households in the database, both participants and non-participants, whereas the second one is reduced to participants only. To further examine the degree of choice that households have in programme participation, we then split the participating sample into three sub-samples with different degrees of stated volunteerism: fully-volunteered, partly-volunteered and non-volunteered households, as defined above.

First, examining the findings for the whole sample, as presented in column 1, we note that, as expected, the driving forces behind participation intensity are land and location characteristics, whereas most demographic variables are found to be non-significant. These findings are in line with previous studies on SLCP participation decisions (Uchida et al., 2007; Xu et al., 2010) and they support the idea of programme participation being largely based on land characteristics, as defined by the programme environmental goals. We find that participation intensity increases significantly with the share of land area contracted to the household, with gentle slopes as well as with steep slopes, and that the estimated marginal effect is twice as large for steep land. In addition, households with a larger size of contracted land also tend on average to participate more intensively in the programme. Our findings also corroborate the hypothesis that, alongside the programme's attributes, better (access to) information about the policy may facilitate more intensive participation, ceteris paribus. We find a negative correlation between the household's distance from an asphalt road and participation intensity, which can be interpreted in terms of remoteness: households living further away from main centres of activities tend to be more isolated from village life than households living closer to the village centre or to an asphalt road. A potential consequence is that these households are less informed about the SLCP, and may have been less likely to participate as much as other households. In contrast, the earlier the households started participating in the programme, the higher their participation intensity, as suggested by the positive and significant association between the years since first conversion and households' participation intensity. Finally, we find a negative and significant correlation between the variable indicating whether any member of the household belongs to the village committee and participation intensity in the SLCP. This finding interestingly contrasts with the summary statistics presented in Table 4: after controlling for household, land and location characteristics, households of village cadres participate significantly less 
Table 4

Summary statistics for SLCP non-participating and participating households.

Author's survey, Zhuozi county, Inner Mongolia, 2006.

\begin{tabular}{|c|c|c|c|c|c|c|}
\hline & \multirow{3}{*}{$\frac{(1)}{\text { Total }}$} & \multirow{3}{*}{$\frac{(2)}{\text { Non-participating }}$} & \multirow{3}{*}{$\frac{(3)}{\text { Participating }}$} & $(4)$ & (5) & \multirow[t]{2}{*}{ (6) } \\
\hline & & & & \multicolumn{2}{|c|}{ Among participating households } & \\
\hline & & & & Fully-volunteered & Partly-volunteered & Non-volunteered \\
\hline \multicolumn{7}{|l|}{ Household demographics } \\
\hline Age of household head & 56.26 & 59.01 & $55.79^{* *}$ & 54.91 & 56.34 & 55.30 \\
\hline Education of household head & 4.983 & 4.464 & $5.071^{*}$ & $5.712^{* * *}$ & $4.625^{* * *}$ & 5.364 \\
\hline Household size & 3.191 & 2.486 & $3.311^{* * *}$ & 3.200 & 3.355 & 3.444 \\
\hline Proportion of adult males & 0.525 & 0.572 & $0.516^{* *}$ & 0.501 & 0.514 & 0.539 \\
\hline Proportion of elderly & 0.173 & 0.330 & $0.146^{* * *}$ & 0.120 & $0.172^{* *}$ & $0.107^{*}$ \\
\hline Proportion of children above 6 & 0.0458 & 0.0469 & 0.0456 & 0.0550 & $0.0384^{*}$ & 0.0521 \\
\hline Proportion of migrant members in 1999 & 0.132 & 0.123 & 0.134 & 0.130 & 0.132 & 0.138 \\
\hline Village committee member & 0.110 & 0.0714 & 0.117 & 0.128 & 0.115 & 0.111 \\
\hline \multicolumn{7}{|l|}{ Land and location characteristics } \\
\hline Total area of plots & 32.61 & 9.563 & $36.53^{* * *}$ & 38.96 & 37.12 & $32.19^{*}$ \\
\hline Total number of plots & 8.944 & 4.500 & $9.701^{* * *}$ & $10.22^{*}$ & 9.760 & $8.963^{* *}$ \\
\hline Average distance of plots to home (in km) & 0.851 & 0.610 & $0.882^{* * *}$ & 0.877 & 0.896 & 0.855 \\
\hline Share of land with gentle slope (\% of total land) & 0.501 & 0.303 & $0.535^{* * *}$ & 0.536 & 0.542 & 0.526 \\
\hline Share of land with steep slope (\% of total land) & 0.178 & 0.0163 & $0.205^{* * *}$ & $0.151^{* * *}$ & $0.228^{* *}$ & 0.208 \\
\hline Household home distance to asphalt road (in $\mathrm{km}$ ) & 3.049 & 3.733 & $2.932^{*}$ & $3.762^{* * *}$ & 2.821 & $1.915^{\text {*** }}$ \\
\hline Household home distance to village centre (in $\mathrm{km}$ ) & 1.216 & 1.936 & $1.093^{* * *}$ & 1.054 & 1.139 & 1.025 \\
\hline \multicolumn{7}{|l|}{ Participation } \\
\hline Voluntary participation & - & - & 0.304 & & & \\
\hline Years since first conversion & - & - & 4.523 & 4.392 & $4.625^{*}$ & 4.469 \\
\hline Share of land area converted & 0.434 & - & 0.507 & $0.477^{* *}$ & 0.518 & 0.521 \\
\hline "Satisfaction" with the programme & - & - & 0.698 & $0.776^{* *}$ & $0.73^{*}$ & $0.506^{\text {*** }}$ \\
\hline Observations & 481 & 70 & 411 & 125 & 200 & 81 \\
\hline
\end{tabular}

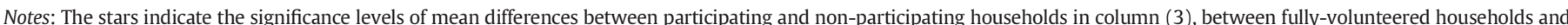

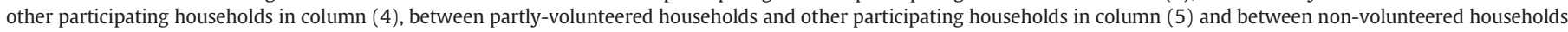

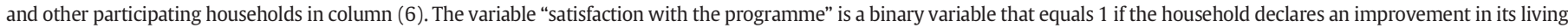
standards after the implementation of the SLCP programme (dependent variable for Table 6).

* Significant at $10 \%$.

** Significant at $5 \%$

*** Significant at $1 \%$.

Table 5

GLM estimates of households' participation intensity in SLCP - marginal effects.

Author's survey, Zhuozi county, Inner Mongolia, 2006.

\begin{tabular}{|c|c|c|c|c|c|}
\hline & $(1)$ & $(2)$ & (3) & $(4)$ & $(5)$ \\
\hline & Full sample & Participants & Non-volunteered & Partly-volunteered & Fully-volunteered \\
\hline Age of household head & $\begin{array}{l}0.000518 \\
(0.698)\end{array}$ & $\begin{array}{l}0.0000242 \\
(0.986)\end{array}$ & $\begin{array}{l}0.00318 \\
(0.458)\end{array}$ & $\begin{array}{l}0.0000749 \\
(0.974)\end{array}$ & $\begin{array}{l}-0.00241 \\
(0.236)\end{array}$ \\
\hline Education of household head & $\begin{array}{l}0.00155 \\
(0.562)\end{array}$ & $\begin{array}{l}0.000966 \\
(0.768)\end{array}$ & $\begin{array}{l}0.0112 \\
(0.141)\end{array}$ & $\begin{array}{l}-0.00618 \\
(0.311)\end{array}$ & $\begin{array}{l}0.00396 \\
(0.411)\end{array}$ \\
\hline Household size & $\begin{array}{l}0.000569 \\
(0.961)\end{array}$ & $\begin{array}{l}-0.00262 \\
(0.783)\end{array}$ & $\begin{array}{l}0.0241^{*} \\
(0.091)\end{array}$ & $\begin{array}{l}0.00471 \\
(0.689)\end{array}$ & $\begin{array}{l}-0.0325^{\text {** }} \\
(0.010)\end{array}$ \\
\hline Proportion of adult males & $\begin{array}{l}0.101 \\
(0.210)\end{array}$ & $\begin{array}{l}0.0584 \\
(0.467)\end{array}$ & $\begin{array}{l}-0.0464 \\
(0.753)\end{array}$ & $\begin{array}{l}-0.0244 \\
(0.835)\end{array}$ & $\begin{array}{l}0.203^{* *} \\
(0.026)\end{array}$ \\
\hline Proportion of elderly & $\begin{array}{l}0.00928 \\
(0.867)\end{array}$ & $\begin{array}{l}0.0534 \\
(0.396)\end{array}$ & $\begin{array}{l}0.0725 \\
(0.569)\end{array}$ & $\begin{array}{l}0.133^{* *} \\
(0.023)\end{array}$ & $\begin{array}{l}-0.112 \\
(0.337)\end{array}$ \\
\hline Proportion of migrant members in 1999 & $\begin{array}{l}0.101 \\
(0.298)\end{array}$ & $\begin{array}{l}0.110 \\
(0.172)\end{array}$ & $\begin{array}{l}0.212^{* *} \\
(0.037)\end{array}$ & $\begin{array}{l}0.0462 \\
(0.567)\end{array}$ & $\begin{array}{l}0.141 \\
(0.274)\end{array}$ \\
\hline Village committee member & $\begin{array}{l}-0.0584^{* * *} \\
(0.008)\end{array}$ & $\begin{array}{l}-0.0493^{* *} \\
(0.032)\end{array}$ & $\begin{array}{l}-0.118 \\
(0.288)\end{array}$ & $\begin{array}{l}-0.0324 \\
(0.312)\end{array}$ & $\begin{array}{l}-0.0245 \\
(0.501)\end{array}$ \\
\hline Home distance to asphalt road (in km) & $\begin{array}{l}-0.0140^{* *} \\
(0.014)\end{array}$ & $\begin{array}{l}-0.0195^{\text {*** }} \\
(0.002)\end{array}$ & $\begin{array}{l}-0.0274^{* *} \\
(0.010)\end{array}$ & $\begin{array}{l}-0.0232^{* * *} \\
(0.000)\end{array}$ & $\begin{array}{l}-0.0147^{* * *} \\
(0.000)\end{array}$ \\
\hline Home distance to village centre (in km) & $\begin{array}{l}-0.0146 \\
(0.210)\end{array}$ & $\begin{array}{l}-0.0156 \\
(0.210)\end{array}$ & $\begin{array}{l}-0.0633^{*} \\
(0.084)\end{array}$ & $\begin{array}{l}0.00313 \\
(0.746)\end{array}$ & $\begin{array}{l}-0.0239 \\
(0.134)\end{array}$ \\
\hline Years since first conversion & $\begin{array}{l}0.0599^{* * *} \\
(0.000)\end{array}$ & $\begin{array}{l}0.00723 \\
(0.599)\end{array}$ & $\begin{array}{l}-0.00662 \\
(0.790)\end{array}$ & $\begin{array}{l}0.0120 \\
(0.230)\end{array}$ & $\begin{array}{l}0.00826 \\
(0.599)\end{array}$ \\
\hline Total area of plots & $\begin{array}{l}0.00411^{* * *} \\
(0.000)\end{array}$ & $\begin{array}{l}0.00414^{* * *} \\
(0.000)\end{array}$ & $\begin{array}{l}0.00343^{*} \\
(0.055)\end{array}$ & $\begin{array}{l}0.00537^{* * *} \\
(0.000)\end{array}$ & $\begin{array}{l}0.00441^{* * *} \\
(0.001)\end{array}$ \\
\hline Total number of plots & $\begin{array}{l}-0.00440 \\
(0.290)\end{array}$ & $\begin{array}{l}-0.0107^{* * *} \\
(0.008)\end{array}$ & $\begin{array}{l}-0.00762 \\
(0.335)\end{array}$ & $\begin{array}{l}-0.0146^{* *} \\
(0.016)\end{array}$ & $\begin{array}{l}-0.0135^{* * *} \\
(0.000)\end{array}$ \\
\hline Share of land area with gentle slope & $\begin{array}{l}0.216^{* * *} \\
(0.007)\end{array}$ & $\begin{array}{l}0.154^{* *} \\
(0.011)\end{array}$ & $\begin{array}{l}0.303^{* * *} \\
(0.000)\end{array}$ & $\begin{array}{l}0.146^{* *} \\
(0.044)\end{array}$ & $\begin{array}{l}0.141 \\
(0.114)\end{array}$ \\
\hline Share of land area with steep slope & $\begin{array}{l}0.432^{* * * *} \\
(0.000)\end{array}$ & $\begin{array}{l}0.345^{* * *} \\
(0.000)\end{array}$ & $\begin{array}{l}0.506^{\text {*** }} \\
(0.000)\end{array}$ & $\begin{array}{l}0.334^{* * *} \\
(0.000)\end{array}$ & $\begin{array}{l}0.318^{* * *} \\
(0.000)\end{array}$ \\
\hline Observations & 474 & 405 & 81 & 200 & 124 \\
\hline
\end{tabular}

Notes: Marginal effects are presented with $p$-values in parentheses and the level of significance $\left({ }^{*} p<0.10,{ }^{* *} p<0.05,{ }^{* * *} p<0.01\right)$. Standard errors are clustered by village. 
intensively. One interpretation could be that, while village cadres may have had to set an example for their village fellows at the beginning of the programme by converting land (as suggested by anecdotal evidence), they refrained from converting intensively and did not try to capture all potential rents associated with conversion. Overall, these first results from the full sample suggest that the intensity of households' participation is primarily driven by land characteristics, which supports the idea that the decision-making process has been driven mainly by the programme's attributes. Estimations on the participating sample only (column 2) confirm these findings and show no strong difference from the full sample estimation, except that among participating households the total number of plots is also negatively associated with participation intensity. This finding may suggest that, once total land area is controlled, households who convert more intensively are those who have less scattered plots on average.

We now turn to the three sub-samples: non-volunteered (column 3 ), partly-volunteered (column 4) and fully-volunteered households (column 5). The comparison of columns 3, 4 and 5 shows that the land and location characteristics identified previously as key drivers of participation intensity are all still significant in the three sub-samples. These findings suggest that the intensity of participation of households in the programme is consistently driven by the opportunity cost of the land, whether they participate voluntarily or not. Nevertheless, the point estimates reveal an interesting gap: for both the share of land area with a steep slope and the home distance to an asphalt road, the estimated coefficients are larger for the regression on the nonvolunteered sample than on the fully volunteered sample. The gap suggests that these variables, which reflect the opportunity cost of the converted land and the transaction cost of the programme's implementation, carried less weight in the decision for households who voluntarily participated compared to those who were forced to convert their land. As such, this confirms that non-volunteered households were selected on the basis of their land characteristics conforming to the programme prerequisites (notably concerning the steepness of the agricultural land's slope), and that this applied to volunteer households as well but in a less systematic way.

Turning to household characteristics, a number of interesting differences arise between the three sub-samples. First, for the nonvolunteered sub-sample, most household characteristics are nonsignificant, which conforms to the idea that those households were primarily selected for their land characteristics. The only household characteristic that appears significant (and positive) for this sub-group is the proportion of migrant members in 1999: households that already had migration activity before the programme was implemented may have been more easily selected to convert their arable land for several reasons. For those households, the programme could represent an opportunity to reduce labour-intensive agricultural activities (Uchida et al., 2007). Village leaders may also have been more likely to select households that had diversified sources of income before the programme was launched, assuming that they would more easily turn to alternative options to agricultural work. Second, in the partlyvolunteered sample, the only household characteristic that is significantly associated with the intensity of participation is the proportion of elderly people (positive correlation). For households who had conversion imposed but were willing to participate, the programme may also have been seen as an opportunity for those with old dependents to retire more land so as to reduce labour-intensive activities. Third, for the fully-volunteered sample, households that convert a higher share of their cultivated land are smaller in size but with a larger proportion of adult males. As for the other sub-samples, labour-force availability seems to be a driver for the intensity of participation: smaller size households may have been willing to take the opportunity to retire land from cultivation and save labour for other activities. On the other hand, the positive association between the proportion of adult males in the household and the intensity of participation could illustrate the fact that a larger labour force also allows diversification towards activities with a higher return (including local off-farm activities or labour migration).

Overall, our findings suggest that the intensity of participation is primarily driven by land characteristics, and this holds true for nonvolunteered households as well as for partly-volunteered and fullyvolunteered households. Going back to our research question on the programme's sustainability, non-significant differences between volunteered and non-volunteered households with respect to land characteristics are somewhat encouraging. Indeed, they suggest that the economic rationale for the intensity of participation based on the conversion of plots with the lowest opportunity cost is not only observed for non-volunteered households but also for volunteered ones.

\subsection{Programme Satisfaction}

As a preliminary step in the analysis of programme satisfaction, the raw statistics displayed in Table 4 show that fully-volunteered households exhibit a significantly higher level of satisfaction (77.6\%) compared to non-volunteered households, which exhibit much lower satisfaction. Only $50.6 \%$ of non-volunteered households report an improvement in their living standards due to SLCP implementation. Table 6 reports estimates of the determinants of programme satisfaction: the first column displays single-equation probit estimates as a comparison basis, and the next three columns show the parameter estimates for the trivariate probit model.

The single-equation probit model and the trivariate probit model show consistent estimates for the determinants of satisfaction with the SLCP. In particular, the positive and significant coefficients for fully and partly voluntary participation indicate that volunteered households are significantly more likely to report an improvement in their living standards than non-volunteered households (the omitted category here). Interestingly, the trivariate probit estimation provides us with a much larger parameter estimate for the partly-volunteered dummy compared to the probit estimation, indicating that the results from the latter are downward biased. This is confirmed by the negative and significant correlation between the error term in the satisfaction equation and the error term of the partly-volunteered participation equation $\left(\sigma_{31}=-0.384\right)$, indicating that unobservable factors which increase the probability of being a partly volunteered household decrease the likelihood of reporting livelihood improvement. In contrast, the correlation between the error term in the satisfaction equation and the error term of the fully-volunteered participation equation is positive $\left(\sigma_{21}=0.288\right)$ and weakly significant, which may explain the slightly lower parameter estimate of the fully-volunteered dummy in the trivariate probit.

The estimates for other covariates in the satisfaction equation show that both the intensity of conversion (share of land area converted) and the (low) quality of land assets (measured by the share of land area with a gentle slope or with a steep slope) significantly affect the probability of households reporting livelihood improvement with the SLCP. In contrast, most demographic variables are not significantly associated with the probability of a positive perception of the impact of the SLCP on households' livelihood. As such, once volunteered participation is controlled for (with volunteered participation being partly determined by demographic variables such as the human capital of the household head), the other household demographic variables, in particular households' composition, are not significantly associated with a higher probability of satisfaction. Furthermore, participation in local political life does not seem to have any strong influence on subjective satisfaction either. Finally, we find that remoteness and income matter for households' satisfaction. Households living further from the village centre are less likely to report positive appreciation of the impact of the SLCP on their living standards whereas, consistently with usual findings on subjective well-being (Ferrer-i-Carbonell, 2005), richer households are, ceteris paribus, more satisfied than their poorer counterparts. 
Table 6

Recursive trivariate probit estimates of satisfaction with SLCP for participating households.

Author's survey, Zhuozi county, Inner Mongolia, 2006.

\begin{tabular}{|c|c|c|c|c|}
\hline & \multirow[t]{2}{*}{ Probit } & \multicolumn{3}{|c|}{ Trivariate probit } \\
\hline & & “Satisfaction” & Fully volunteered & Partly volunteered \\
\hline Fully-volunteered participation & $\begin{array}{l}0.737^{* * *} \\
(0.274)\end{array}$ & $\begin{array}{l}0.603^{* *} \\
(0.307)\end{array}$ & & \\
\hline Partly-volunteered participation & $\begin{array}{l}0.527^{* * *} \\
(0.165)\end{array}$ & $\begin{array}{l}1.109^{* * * *} \\
(0.253)\end{array}$ & & \\
\hline Years since first conversion & $\begin{array}{l}0.0603 \\
(0.0524)\end{array}$ & $\begin{array}{l}0.0578 \\
(0.0486)\end{array}$ & & \\
\hline Share of land area converted & $\begin{array}{l}0.703^{* *} \\
(0.325)\end{array}$ & $\begin{array}{l}0.676^{* *} \\
(0.316)\end{array}$ & & \\
\hline Age of household head & $\begin{array}{l}-0.00610 \\
(0.00812)\end{array}$ & $\begin{array}{l}-0.00196 \\
(0.00815)\end{array}$ & $\begin{array}{l}0.0102 \\
(0.0101)\end{array}$ & $\begin{array}{l}-0.0127 \\
(0.0102)\end{array}$ \\
\hline Education of household head & $\begin{array}{l}0.0115 \\
(0.0290)\end{array}$ & $\begin{array}{l}0.0271 \\
(0.0277)\end{array}$ & $\begin{array}{l}0.0530^{* * *} \\
(0.0169)\end{array}$ & $\begin{array}{l}-0.0632^{* * *} \\
(0.0227)\end{array}$ \\
\hline Village committee member & $\begin{array}{l}0.326 \\
(0.218)\end{array}$ & $\begin{array}{l}0.288 \\
(0.192)\end{array}$ & $\begin{array}{l}0.0193 \\
(0.269)\end{array}$ & $\begin{array}{l}0.0576 \\
(0.197)\end{array}$ \\
\hline Household size & $\begin{array}{l}-0.0220 \\
(0.0617)\end{array}$ & $\begin{array}{l}-0.0405 \\
(0.0554)\end{array}$ & $\begin{array}{l}-0.108 \\
(0.0761)\end{array}$ & $\begin{array}{l}0.0667 \\
(0.0564)\end{array}$ \\
\hline Proportion of elderly & $\begin{array}{l}0.197 \\
(0.270)\end{array}$ & $\begin{array}{l}0.0404 \\
(0.240)\end{array}$ & $\begin{array}{l}-0.358 \\
(0.356)\end{array}$ & $\begin{array}{l}0.560 \\
(0.363)\end{array}$ \\
\hline Proportion of children above 6 & $\begin{array}{l}-1.172^{*} \\
(0.654)\end{array}$ & $\begin{array}{l}-0.655 \\
(0.546)\end{array}$ & $\begin{array}{l}0.908 \\
(0.624)\end{array}$ & $\begin{array}{l}-1.286^{* *} \\
(0.551)\end{array}$ \\
\hline Proportion of adult males & $\begin{array}{l}-0.306 \\
(0.381)\end{array}$ & $\begin{array}{l}-0.210 \\
(0.382)\end{array}$ & $\begin{array}{l}-0.359 \\
(0.564)\end{array}$ & $\begin{array}{l}-0.186 \\
(0.342)\end{array}$ \\
\hline Proportion of migrant members in 1999 & $\begin{array}{l}-0.735^{* *} \\
(0.352)\end{array}$ & $\begin{array}{l}-0.658^{*} \\
(0.356)\end{array}$ & $\begin{array}{l}0.419 \\
(0.331)\end{array}$ & $\begin{array}{l}-0.361 \\
(0.235)\end{array}$ \\
\hline Total area of plots & $\begin{array}{l}0.0000100 \\
(0.00341)\end{array}$ & $\begin{array}{l}0.000285 \\
(0.00288)\end{array}$ & $\begin{array}{l}0.00202 \\
(0.00191)\end{array}$ & $\begin{array}{l}-0.00187 \\
(0.00164)\end{array}$ \\
\hline Share of gentle slope land area & $\begin{array}{l}1.003^{* * *} \\
(0.265)\end{array}$ & $\begin{array}{l}0.845^{* * *} \\
(0.263)\end{array}$ & $\begin{array}{l}-0.511^{* *} \\
(0.255)\end{array}$ & $\begin{array}{l}0.390 \\
(0.328)\end{array}$ \\
\hline Share of steep slope land area & $\begin{array}{l}0.814^{* *} \\
(0.330)\end{array}$ & $\begin{array}{l}0.597^{* *} \\
(0.271)\end{array}$ & $\begin{array}{l}-0.974^{* * *} \\
(0.194)\end{array}$ & $\begin{array}{l}0.387 \\
(0.308)\end{array}$ \\
\hline Home distance to asphalt road (in km) & $\begin{array}{l}0.0431 \\
(0.0416)\end{array}$ & $\begin{array}{l}0.0383 \\
(0.0354)\end{array}$ & $\begin{array}{l}0.00492 \\
(0.0141)\end{array}$ & $\begin{array}{l}0.0164^{*} \\
(0.00844)\end{array}$ \\
\hline Home distance to village centre (in km) & $\begin{array}{l}-0.122^{* *} \\
(0.0496)\end{array}$ & $\begin{array}{l}-0.123^{* * *} \\
(0.0477)\end{array}$ & $\begin{array}{l}-0.0485 \\
(0.0468)\end{array}$ & $\begin{array}{l}0.0402 \\
(0.0393)\end{array}$ \\
\hline Log (per capita family income) & $\begin{array}{l}0.102^{* *} \\
(0.0457)\end{array}$ & $\begin{array}{l}0.102^{* *} \\
(0.0427)\end{array}$ & & \\
\hline Income gap to reference group (village) & $\begin{array}{l}0.430^{*} \\
(0.232)\end{array}$ & $\begin{array}{l}0.404^{*} \\
(0.208)\end{array}$ & & \\
\hline Village share of fully- volunteered participants & & & $\begin{array}{l}0.0265^{* * *} \\
(0.00755)\end{array}$ & \\
\hline Village share of partly- volunteered participants & & & & $\begin{array}{l}0.0295^{* * *} \\
(0.00274)\end{array}$ \\
\hline $\mathrm{N}$ & 405 & 405 & 405 & 405 \\
\hline Likelihood ratio test of $\sigma_{21}=\sigma_{31}=\sigma_{32}$ & & $\begin{array}{l}\sigma_{21} \\
0.288^{*} \\
(0.165) \\
\chi^{2}=178^{* * *}\end{array}$ & $\begin{array}{l}\sigma_{31} \\
-0.384^{* * *} \\
(0.146)\end{array}$ & $\begin{array}{l}\sigma_{32} \\
-0.913^{* * *} \\
(0.027)\end{array}$ \\
\hline
\end{tabular}

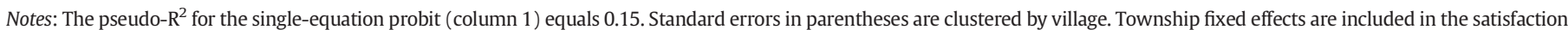
equation.

$* p<0.10$.

** $p<0.05$.

$* * * \quad p<0.01$.

To summarize, the results indicate that the probability of households reporting the SLCP having a positive impact on their living standards is largely associated with the households' volunteerism, as well as with their intensity of participation. It is also positively correlated with a lower quality of land and a higher absolute income level, and negatively correlated with households living in more remote areas. The fact that volunteerism is significantly and positively associated with the probability of reporting satisfaction hints at possible difficulties encountered by non-volunteered households during the conversion of their land or at disappointment with respect to the economic benefits offered by it.

\section{Conclusion}

Using microeconomic data from a household survey conducted in 2006 in Inner Mongolia, we explored the role of stakeholder engagement and its implications for the long-term sustainability of the Sloping
Land Conversion Programme. Based on the idea that volunteerism and satisfaction with the programme's outcome are two important components of the programme's viability, we successively analysed the intensity of households' participation in the programme and their reported satisfaction with its economic achievement, which we related to their stated volunteerism.

We found that households' participation intensity in the SLCP is primarily driven by land and location characteristics, and that these results hold true whether or not the households voluntarily enrolled in the programme. These findings are in accordance with the idea that programme attributes are the driving forces behind the decision-making process in the SLCP (Mullan and Kontoleon, 2012; Uchida et al., 2007; Xu et al., 2010). The comparison between types of households adds an interesting nuance since the opportunity cost of the land converted and the transaction cost of programme implementation are found to carry less weight in the decision making for households who voluntarily 
converted their land compared to those who were forced to do so. As such, this confirms that non-volunteered households were selected on the basis of their land characteristics conforming to the programme prerequisites, and that this applied to volunteered households as well but in a less systematic way. The fact that the targeting of land for conversion was mainly based on land characteristics, with little evidence of mis-targeting, gives support for the economic sustainability of the programme, at least as far as land is concerned.

The extent to which participation is perceived as bringing about benefits for participant households is also important for the long-term sustainability of the programme. As such, having established that land targeting for conversion was relatively exogenous to households' characteristics, we then examined participants' ex-post satisfaction with the SLCP. We found that both fully and partly-volunteered households were more likely to report satisfaction compared to non-volunteered households, ceteris paribus, and that active participation increased satisfaction. As far as participants' satisfaction can be interpreted as an indicator of continued interest in (and potential long-term support for) the programme, these findings add evidence supporting plausible longterm sustainability. On the other hand, the fact that the probability of reporting satisfaction is strongly associated with volunteerism hints at possible difficulties that non-volunteered households may have encountered during the conversion of their land or disappointment with respect to the economic benefits of the programme. If this is the case, then non-volunteered households may be more prone to reconverting their land after the programme ends, which may threaten the overall sustainability of the programme in the long run.

\section{References}

Bennett, M.T., 2008. China's sloping land conversion program: institutional innovation or business as usual? Ecol. Econ. 65 (4), 699-711.

Brandt, L., Huang, J., Li, G., Rozelle, S., 2002. Land rights in rural China: facts, fictions and issues. China J. 47, 67-97.

Bulte, E.H., Lipper, N.L., McCartney, R., Stringer, R., Zilberman, D., 2008. Paying for ecosystem services: an introduction to the special issue. Environ. Dev. Econ. 13 (3), 245-254.

Cappellari, L., Jenkins, S.P., 2003. Multivariate probit regression using simulated maximum likelihood. Stata J. 3 (3), 278-294.

Démurger, S., Wan, H., 2012. Payments for ecological restoration and internal migration in China: the sloping land conversion program in Ningxia. IZA J. Migr. 1, 10.

Engel, S., Pagiola, S., Wunder, S., 2008. Designing payments for environmental services in theory and practice: an overview of the issues. Ecol. Econ. 65 (4), 663-674.

Feng, Z., Yang, Y., Zhang, Y., Zhang, P., Li, Y., 2005. Grain-for-green policy and its impact on grain supply in West China. Land Use Policy 22, 301-312.

Ferrer-i-Carbonell, A., 2005. Income and well-being: an empirical analysis of the comparison income effect. J. Public Econ. 89, 997-1019.

Gauvin, C., Uchida, E., Rozelle, S., Xu, J., Zhan, J., 2010. Cost-effectiveness of payments for ecosystem services with dual goals of environment and poverty alleviation. Environ. Manag. 45, 488-501.
Groom, B., Grosjean, P., Kontoleon, A., Swanson, T., Zhang, S., 2010. Relaxing rural constraints: a 'win-win' policy for poverty and environment in China? Oxf. Econ. Pap. 62 (1), 132-156.

Grosjean, P., Kontoleon, A., 2009. How sustainable are sustainable development programs? The case of the Sloping Land Conversion Program in China. World Dev. 37 (1), 268-285.

Liang, Y., Li, S., Feldman, M.W., Daily, G.C., 2012. Does household composition matter? The impact of the Grain for Green Program on rural livelihoods in China. Ecol. Econ. 75, $152-160$

Liu, C., Lu, J., Yin, R., 2010. An estimation of the effects of China's Priority Forestry Programs on farmers' income. Environ. Manag. 45 (3), 526-540.

Mullan, K., Kontoleon, A., 2012. Participation in Payments for Ecosystem Services programmes: accounting for participant heterogeneity. J. Environ. Econ. Policy 1 (3), 235-254.

Muradian, R., Corbera, E., Pascual, U., Kosoy, N., May, P.H., 2010. Reconciling theory and practice: an alternative conceptual framework for understanding payments for environmental services. Ecol. Econ. 69 (6), 1202-1208.

Papke, L.E., Wooldridge, J.M., 1996. Econometric methods for fractional response variables with an application to 401(k) plan participation rates. J. Appl. Econ. 11 (6), 619-632.

Rodríguez, L.C., Pascual, U., Muradian, R., Pazmino, N., Whitten, S., 2011. Towards a unified scheme for environmental and social protection: Learning from PES and CCT experiences in developing countries Ecol. Econ. 70 (11), 2163-2174.

Shi, M., Chen, K., 2004. Land degradation, government subsidy, and smallholders' conservation decision: the case of the loess plateau in China. J. Zhejiang Univ. (Sci.) 5 (12), 1533-1542.

Sommerville, M., Jones, J., Rahajaharison, M., Milner-Gulland, E.J., 2010. The role of fairness and benefit distribution in community-based Payment for Environmental Services interventions: a case study from Menabe, Madagascar. Ecol. Econ. 69 (6), $1262-1271$

Uchida, E., Xu, J., Rozelle, S., 2005. Grain for Green: cost-effectiveness and sustainability of China's conservation set-aside program. Land Econ. 81 (2), 247-264.

Uchida, E., Xu, J., Xu, Z., Rozelle, S., 2007. Are the poor benefiting from China's land conservation program? Environ. Dev. Econ. 12, 593-620.

Uchida, E., Rozelle, S., Xu, J., 2009. Conservation payments, liquidity constraints and off-farm labor: impact of the Grain for Green Program on rural households in China. Am. J. Agric. Econ. 91 (1), 70-86.

Wunder, S., 2005. Payments for environmental services: some nuts and bolts. CIFOR Occasional Paper 42. Center for International Forestry Research. Bogor, Indonesia.

Xu, J., Cao, Y., 2001. The socioeconomic impacts and sustainabilityof the SLCP. In: Xu, Jintao, Katsigris, Eugenia, White, Thomas A. (Eds.), Implementing the Natural Forest Protection Programand the Sloping Land Conversion Program: Lessons and Policy Recommendations. CCICED-Task Force on Forests and Grasslands. China Forestry Publishing House, Beijing.

Xu, Z., Xu, J., Deng, X., Huang, J., Uchida, E., Rozelle, S., 2006a. Grain for Green versus grain: conflict between food security and conservation set-aside in China. World Dev. 34 (1), 130-148.

Xu, J., Yin, R., Li, Z., Liu, C., 2006b. China's ecological rehabilitation: unprecedented efforts, dramatic impacts, and requisite policies. Ecol. Econ. 57, 595-607.

Xu, J., Bennett, M., Tao, R., Xu, Z., 2010. China's Sloping Land Conversion Program: does expansion equal success? Land Econ. 86 (2), 219-244.

Yao, S., Guo, Y., Huo, X., 2010. An empirical analysis of the effects of China's Land Conversion Program on farmers' income growth and labor transfer. Environ. Manag. 45 (3), 502-512.

Yin, R., Yin, G., Li, L., 2010. Assessing China's ecological restoration programs: what's been done and what remains to be done? Environ. Manag. 45 (3), 442-453.

Zuo, T., 2001. Implementation of the SLCP. In: Xu, J., Katsigris, E., White, T.A. (Eds.), Implementing the Natural Forest Protection Program and the Sloping Land Conversion Program: Lessons and Policy Implications, CCICED. China Forestry Publishing House, Beijing. 